\title{
A HIPOFRONTALITÁS VIZSGÁLATA SZKIZOFRÉN BETEGEKNÉL NEUROPSZICHOLÓGIAI TESZTEKKEL
}

\author{
SZABÓ JUDIT \\ Országos Orvosi Rehabilitációs Intézet \\ Semmelweis Orvostudományi Egyetem Doktori Iskola \\ E-mail: yukiko@freemail.hu
}

\begin{abstract}
A homloklebeny szerepére a szkizofrénia tüneteinek kialakulásában azon klinikai megfigyelések hívták fel a figyelmet, amelyek szerint ezen - elsösorban negatív - tünetek hasonlóak a frontális lebeny, különösen a prefrontális régió léziója esetén tapasztalható szimptómákhoz (BÁNKI, 1994). Ezt a hipotézist mind strukturális és funkcionális agyi képalkotó eljárások (DABASI, 1994; KENÉZ, 1994; DEGRELL, 1998), mind neuropszichológiai tesztek (LEVIN, YURGELUN-TODD, CRAFT, 1989; JESTE, GALASKO, COREY-BLOOM, WALENS, GRANHOLM, 1996) alkalmazásával sikerült alátámasztani.

A tanulmány alapjául szolgáló vizsgálat célja a frontális lebeny diszfunkciójára utaló jegyek neuropszichológiai módszerekkel történö megragadása volt. A vizsgálatban a tartós és incidentális figyelmet, a verbális és téri-vizuális rövid távú memóriát, a vizuopercepciót és -konstrukciót mérö neuropszichológiai tesztek és egyszerü motoros próbák eredményei alapján hasonlítottunk össze szkizofrén betegeket és egészséges kontrollszemélyeket. Hipotézisünk szerint a szkizofrén csoport szignifikánsan rosszabb teljesítményt nyújt frontális lebeny diszfunkciójára érzékeny tesztekben, mint a kontrollszemélyek, és a mennyiségi különbség mellett minőségbeli eltérés is mutatkozik a két csoport teljesítménye között. A kapott eredmények kvantitatív és kvalitatív elemzése megerösitette a hipotézist; a szkizofrén betegek teljesítménycsökkenése elsösorban a gyakori perszeverációs hibákra, az aktív szervezés és tervezés hiányára és a nagyfokú figyelmi deficitre vezethetö vissza. E vizsgálat bemutatásán keresztül az elöadás célja az, hogy rámutasson a neuropszichológiai vizsgálóeljárások pszichiátriai betegeknél történő alkalmazásának hasznosságára a komplexebb diagnosztikai munka, terápiás terv és rehabilitációs program kialakitásában.
\end{abstract}

Kulcsszavak: $\quad$ hipofrontalitás, kognitív deficit, perszeveráció, figyelemzavar, tervezés zavara

A szkizofréniakutatás régóta foglalkozik a frontális lebeny szerepével a kórkép patomechanizmusában, különös tekintettel a prefrontális régióra. A cikk alapjául szolgáló vizsgálat célja a szkizofrénia hátterében sokak által feltételezett és kimu- 
tatott „hipofrontalitás” jelenségének vizsgálata neuropszichológiai tesztek alkalmazásával. A szkizofréniában tapasztalható kognitív deficitek egy része - többek között a figyelem, a memória és a tervezés zavara - a frontális lebeny károsodásakor észlelhető tünetek jellegzetességeit mutatja. Több, a szkizofrén betegek mentális működését vizsgáló tanulmány eredményei szerint ezek a betegek az egészséges személyeknél szignifikánsan rosszabb teljesítményt nyújtanak a frontális funkciókra érzékeny neuropszichológiai tesztekben. E következtetéseket alátámasztják az agyi képalkotó vizsgálatok (CT, MRI, PET, SPECT) eredményei is, melyek szerint szkizofrén betegeknél strukturális és funkcionális eltérések tapasztalhatók a frontális lebenyben, különösen a prefrontális régióban. A funkcionális képalkotó eljárások alkalmazásával többen csökkent mértékủ vérátfolyást találtak szkizofrén betegek frontális lebenyében nyugalmi helyzetben és kognitív tesztfeladatok végrehajtása közben (Franzen, IngVAR, 1975; Berman, Illowsky, WEINBERGER, 1988; Weinberger, Berman, Illowsky, 1988; Paulman, Devous, Gregory, HERMAN, 1990). További eredmények szerint a frontális lebeny fokozott múködését igénylő kognitív feladatok megoldása közben szkizofrén személyeknél nem jött létre olyan mértékủ aktivitásfokozódás a homloklebenyben, mint amilyen az egészséges kontrollszemélyeknél volt tapasztalható (BUCHSBAUM, NUECHTERLEIN, Haier, Wu, Sicotte, Hazlett, Asarnow, Potkin, Guich, 1990; Stevens, GOLDMAN-RAKIC, GORE, 1998). Strukturális eltéréseket is leírtak szkizofrén betegeknél a frontális és temporális agyi régiókban (SEIDMAN, YURGELUN-TODD, Kremen, Woods, Goldstein, Faraone, 1994; Cannon, van ErP, Huttunen, 1998), valamint fordított irányú összefüggést találtak a strukturális patológia súlyossága és az érintett agyterület vérátfolyásának mértéke között (BERMAN, WEINBERGER, Shelton, ZEC, 1987). A digitális képalkotó eljárások tehát rávilágítottak a frontális lebeny funkcionális és strukturális eltéréseire szkizofrén személyeknél, ezzel támogatva a frontális lebenynek a kórkép patomechanizmusában betöltött szerepére vonatkozó koncepciót.

\section{SZKIZOFRÉN BETEGEK KOGNITÍV ZAVARAIT VIZSGÁLÓ KUTATÁSOK: A HIPOFRONTALITÁS NEUROPSZICHOLÓGIAI BIZONYÍTÉKAI}

Az elmúlt évtizedekben sokan vizsgálták szkizofrén betegek kognitív működését neuropszichológiai tesztek segítségével, és az évek során így összegyűlt adatok azt bizonyítják, hogy a szkizofrének nagy részénél kimutathatók a figyelem, az információfeldolgozás, a tanulás, a memória, a végrehajtó funkciók, a motoros tevékenység, a téri képességek és a nyelv zavarai (LEvin, YURGELUN-TODD, CRAFT, 1989). TAYLOR és ABRAMS (1984) szkizofrén betegek és egészséges kontrollszemélyek nagy mintáján felvett neuropszichológiai tesztek eredményei szerint a betegek 75\%-a közepes vagy súlyos mértékủ kognitív deficitet mutatott, melyek nagy része bilaterális, de főleg domináns oldali frontotemporális diszfunkciót jelez.

A legtöbb szkizofrén betegnél szembetűnő a nagyfokú figyelemzavar, amely sokak szerint felelőssé tehető a szkizofréniában előforduló többi kognitív deficitért is. Figyelemzavar elsősorban akkor jelentkezik, amikor az adott feladat komplex 
információfeldolgozást igényel; egyszerủbb feladatoknál a betegek nem hibáznak többet, mint az egészséges személyek (JESTE, Galasko, COREY-BloOM, WaLENS, GRANHOLM, 1996). A problémák gyökere a nagymértékű elterelhetőség; úgy tűnik, a szkizofrén betegek nem képesek sokáig egy helyre összpontosítani figyelmüket. Ennek az lehet az oka, hogy a beérkező információhalmazból nem tudják kiszürni a fontos és hasznos adatokat, így az irreleváns információk is elvonják a feldolgozási kapacitást (GRAY, Feldon, RAwLins, Hemsley, SMITH, 1991).

A figyelem vizsgálatára gyakran alkalmazzák a SOA (Scan of Apprehension) feladatot, amelyben a kísérleti személyeknek több vizuális inger (általában betűk) közül kell kiválasztani a célingereket ( $\mathrm{T}$ vagy $\mathrm{F}$ betű) (JESTE, GALASKO, COREYBLOOM, WALENS, GRANHOLM, 1996). A szkizofrén kísérleti betegek szignifikánsan kevesebb célingert találnak meg, mint az egészséges kontrollszemélyek.

Hasonlóképpen az egyszerü reakcióidő-feladatokban is rosszabb teljesítményt nyújtanak a szkizofrének, mint a kontrollszemélyek (JESTE, GALASKO, COREYBLOOM, WALENS, GRANHOLM, 1996). Nemcsak a reakcióidejük hosszabb, hanem a válaszra felkészítő ingerek alkalmazása esetén sem csökken szignifikánsan a válaszadás ideje, azaz a szkizofrén betegek nem tudják kamatoztatni az inger prediktív voltát. DAWSOn, HAZlETt, FiLION, NueChTERLEIn (1993) megfigyelései szerint míg az egészséges személyeiknél csökkent az orientációs reakció intenzitása, ha van előrejelző inger, addig a viszonylag tünetmentes szkizofrén kísérleti személyeknél a prediktív inger ellenére sem módosult az orientációs reakció. Posner, Early, Reiman, Pardo, DhaWan (1988, idézi Levin, Yurgelun-Todd, CRAFT, 1989) szkizofrén kísérleti személyeik vizuális figyelmi feladatban mért megnyúlt reakcióidejét úgy értelmezték, hogy a betegek nehezen tudják elvonni a figyelmüket egy bizonyos ingerről és átirányítani egy másikra.

A CPT (Continuous Performance Test) szintén a tartós figyelem próbája: a vizsgálati személynek le kell nyomnia egy gombot, ha az előzőleg már bemutatott célinger (szám vagy betű) feltủnik a random módon egyenként exponált betűk vagy számok sorozatában (JESTE, GALASKO, COREY-BLOOM, WALENS, GRANHOLM, 1996). Ezt az eljárást alkalmazták Buchsbaum, Nuechterlein, Haier, WU, SicotTe, Hazlett, Asarnow, PotKin és Guich (1990), miközben a glukózmetabolizmust is mérték PET technikával. A szkizofrén vizsgálati személyeknél szignifikánsan több kihagyást és téves riasztást tapasztaltak, mint a kontrollcsoport tagjainál, és a feladat végzése közben abszolút és relatív hipofrontalizációt regisztráltak a betegeknél. Cullum, Harris, Waldo és SMernoff (1993) a tartós figyelmet vizsgálták számjegyáthúzásos feladattal, és azt találták, hogy a szkizofrén betegek több időt igényeltek a feladat végrehajtásához, mint a kontrollszemélyek. Kiváltott potenciál vizsgálatot is végeztek közben (P50), és eredményeik arra utalnak, hogy szkizofréniában a szenzoros szürés neurofiziológiai deficitje áll a fenntartott figyelem zavarának hátterében.

A figyelmi deficitet sokan a szelektív figyelem zavarának tartják. Ezen álláspont szerint a problémát vagy az okozza, hogy túl sok - és gyakran irreleváns - információ kerül felvételre, vagy az, hogy az információ torzul az integráció zavarai miatt. A másik felfogás szerint a figyelemzavar az általános kognitív meglassúbbodás eredménye (Levin, Yurgelun-Todd, Craft, 1989). A szkizofréniában ta- 
pasztalható figyelmi deficit a frontális lebeny diszfunkciójára utal. KinSBOURNE és Hicks (1978; idézi Jeste, GALASKO, COREY-BloOM, WALENS, GRANHOLM, 1996) szerint a frontális lebeny a talamusz segítségével összehangolja a szenzoros inputot a kérgi forráskészletekkel, és a középagyi retikuláris hálózaton keresztül aktiválja a megfelelő forráskészletet. Szkizofréniában ez a funkció szenved zavart vagy mert a frontális lebeny nem képes aktiválni a megfelelő kérgi területet, vagy mert nem képes megszủrni a talamuszból érkező információözönt.

Szkizofrén betegeknél a memóriafunkciók zavarai is megfigyelhetők. Az erre vonatkozó kutatások összefoglalásaként elmondható, hogy mind a verbális, mind a vizuális memória érintett (LEVIN, YURGELUN-TODD, CRAFT, 1989; JESTE, GALASKO, Corey-Bloom, Walens, Granholm, 1996). Saykin, Shtasel és Gur (1994) drog naiv első schubos szkizofrén betegekkel végzett vizsgálatának eredményei szerint a verbális tanulás és memória károsodása a legmarkánsabb kognitív deficit szkizo-fréniában. WEXLER, STEVENS és BOWERS (1998) auditív verbális és nonverbális memóriafeladatokat adtak kísérleti személyeiknek; a verbális feladat szólisták megtanulásából állt, a nem verbális próba pedig különböző frekvenciájú hangok megjegyzését és felismerését igényelte. Az eredmények szerint a verbális memóriafeladatban a szkizofrének szignifikánsan rosszabb teljesítményt nyújtottak, mint a kontrollcsoport tagjai, azonban a nem verbális auditív feladatban csak a figyelemzavarral is jellemezhető szkizofrén betegeknél mutatkozott deficit. Hasonló eredménnyel zárták vizsgálatukat STEvens, GOLDMAN-RAKIC és GORE (1998) is.

Számos vizsgálat eredményei utalnak arra, hogy a szkizofrén betegek verbális memóriájának károsodása hátterében kódolási deficit áll (LEVIN, YURGELUNTODD, CRAFT, 1989). Azért rosszabb az emlékezeti teljesítményük, mint az egészséges személyeké, mert nem képesek megfelelően szervezni az információt, nem tudják kihasználni a helyzet adta kategorizációs lehetőségeket (JESTE, GALASKO, COREY-BloOM, Walens, Granholm, 1996). Maher, Manschreck és RucKlos (1980) vizsgálatában a kísérleti személyeknek tízszavas listákat kellett megtanulniuk és felidézniük. A listák különböztek „kontextuális kényszer” tekintetében, azaz egyes listák random szavakból álltak, míg a többi listában a szavak összefüggő szöveget alkottak. Az eredmények szerint a gondolkodási zavarral jellemezhető szkizofrén vizsgálati személyek kevésbé képesek profitálni a kontextus kínálta lehetőségekből, mint a gondolkodási zavarral nem rendelkező szkizofrén betegek vagy az egészséges kontrollszemélyek. SENGEL és LOVALLO (1983) vizsgálatukban 24 szóból álló kategorizált listákat adtak kísérleti személyeiknek. Az eredmények szerint a szabad felidézési helyzetben a szkizofrén betegek rosszabbul teljesítettek, mint a depressziós betegek vagy az egészséges kontrollszemélyek, és nagyobb volt esetükben a felejtés mértéke is két ülés között. Az eredmények arra utalnak, hogy a szkizofrén betegek amellett, hogy nem szervezik aktívan az információt, érzékenyek az interferenciahatásokra is. GOLD, RANDOLPH, CARPENTER és GOLDBERG (1992) vizsgálati eredményei szerint a felidézés, a felismerés és a szemantikus kódolás is károsodott szkizofréniában, amely a frontális és temporális lebeny diszfunkciójára utal.

FRAME és OLTMANS (1982) a verbális memóriát vizsgálták szkizofrén betegeknél közvetlenül hospitalizálás után, majd a kórházból való hazatérés után. A kór- 
házba kerüléskor a szkizofrének teljesítménye a rövid szólisták felidézésében roszszabb volt, mint a depressziós vagy a kontrollcsoport tagjaié. A kórházból való kikerülés után javult a teljesítmény, ám még remisszióban is maradtak vissza kognitív deficitek. A szerzők következtetései egybevágnak az eddig idézett vizsgálati eredményekkel; a verbális memória károsodásának eredete szkizofréniában az aktív szervezési folyamatok deficitjében rejlik.

A végrehajtó funkciók károsodása igen markáns kognitív deficit szkizofréniában. Ezek vizsgálatára leggyakrabban a Wisconsin kártyaszortírozó tesztet (WCST) alkalmazták a szkizofréniakutatásban (WEINBERGER, BERMAN, ILlOWSKY, 1988; LEVIN, YURGELUN-TODD, CRAFT, 1989). Az így kapott eredmények szerint a szkizofrének kevesebb kategóriával dolgoznak és többet perszeverálnak, mint az egészséges kontrollszemélyek vagy akár más betegcsoportok. A kategorizációs folyamatok deficitjére utalnak CHEN, WiLKins és MCKENNA (1994) kísérletének eredményei is. A szerzők szerint szkizofréniában megtartott a belső kategóriastruktúra, ám a kategóriák határa kitolódik, ezért sokszor olyan szavakat is besorolnak egyegy kategóriába, amelyek valójában nem tartoznak oda.

A végrehajtó funkciók károsodása a kategorizáción kívül a csökkent verbális fluenciában, a pszichomotoros meglassulásban és az információk idői szervezésében megjelenő deficitben is megmutatkozik (JeSTE, GALASKO, COREY-BloOM, Walens, Granholm, 1996). Schwartz, Rosse és Deutsch (1992) vizsgálati eredményei szerint szkizofréniában károsodott a procedurális tanulás és az események idői sorrendjére való emlékezés. A tanulás deficitje a motoros próbákban a viselkedéstervezés zavarára vezethető vissza, és az idői integráció deficitje okozza a sorrendiségre való emlékezés károsodását. A végrehajtó funkciók zavarát frontális diszfunkció okozza, amely ugyan megtalálható más kórképek hátterében is, ám az ezáltal előidézett deficitek jellege szkizofréniában specifikus mintázatot mutat (LeVIn, YuRgelun-Todd, Craft, 1989).

A figyelem, a tanulás, a memória és a végrehajtó funkciók mellett szkizofréniában a téri-vizuális képességek terén is mutatkozik deficit. Bár az erre vonatkozó vizsgálatok eredményei ellentmondásosak, annyi bizonyos, hogy míg az egyszerü vizuoperceptuális és vizuokonstrukciós tesztek megoldásában a szkizofrén betegek nem mutatnak nehézséget, addig a komplexebb elemek integrációját igénylő feladatokban szignifikánsan rosszabb teljesítményt nyújtanak, mint az egészséges vizsgálati személyek (LEVIN, YURGELUN-TODD, CRAFT, 1989).

A fentiekben idézett vizsgálatok eredményei főleg a frontális kognitív funkciók zavarainak sajátos mintázatát tükrözik szkizofréniában. A továbbiakban ismertetjük vizsgálatunkat, amelyben a tartós és incidentális figyelmet, a verbális, vizuális és téri-vizuális memóriát, a vizuopercepciót és -konstrukciót mérő neuropszichológiai tesztek, valamint a mozgásprogramozást tükröző egyszerủ motoros próbák alkalmazásával próbáljuk megragadni a hipofrontalitás jelenségét. Hipotézisünk szerint a szkizofrén betegek szignifikánsan rosszabb teljesítményt nyújtanak e tesztekben a mennyiségi mutatók alapján, mint a kontrollszemélyek. Feltételezzük továbbá, hogy szkizofrén vizsgálati személyeknél olyan specifikus, a homloklebeny diszfunkciójára utaló hibák fordulnak elő, melyek - feltehetően a gyógyszerek hatásai mellett - felelőssé tehetők a teljesítményromlásért. 


\section{A VIZSGÁLT SZEMÉLYEK}

A vizsgálatban 10 szkizofrén beteg és 10 egészséges kontrollszemély vett részt, mindannyain jobbkezesek. A szkizofrén csoport az Országos Pszichiátriai és Neurológiai Intézetben kezelt hét hospitalizált és három ambuláns betegből állt. Kezelőorvosaik diagnózisa alapján kerültek be a mintába. A hosszan tartó neuoleptikus kezelés és a reziduális tünetek negatív hatásait kiküszöbölendő, fiatal, 18 és 32 életév közötti betegeket választottunk a vizsgálathoz, átlagos életkoruk 24,7 év $(S=5,677)$. A csoportot alkotó 5 nő és 5 férfi iskolai végzettsége az elvégzett osztályok számát véve alapul 11,2 év $(\mathrm{S}=1,549)$. A betegek közül négyen első epizódos betegek, a kórkép tünetei náluk fél-egy éve jelentkeztek először, a többi beteg krónikus szkizofrén. Betegségük átlagos időtartama - az első schubos betegeknél ezt egy évnek számolva $-4,5$ év $(S=4,12)$. Fontos szempont volt a betegek kiválasztásánál - természetesen a beleegyezésük mellett - az együttműködés és a motiváltság. További kritérium volt, hogy a betegeknek ne legyenek súlyos defektus tüneteik, jól lehessen velük kontaktust teremteni és kommunikálni, és a vizsgálat időpontjában ne uralják a kórképet pozitív tünetek vagy nagymértékű szorongás. A tíz beteg közül kilencen részesültek neuroleptikus (az esetek többségében Leponex) kezelésben a tesztfelvétel időpontjában, és az antipszichotikumok mellett nyolcan kaptak benzodiazepin-származékokat szorongáscsökkentés céljából.

A kontrollcsoportot 20 és 36 év közötti egészséges személyek, 5 nő és 5 férfi alkotta. Kor, nem vagy iskolázottság tekintetében nem különböznek a szkizofrén betegek csoportjától. Átlagos életkoruk 26,2 év $(\mathrm{S}=4,9)$, mindannyian középfokú végzettséggel rendelkeznek (elvégzett osztályok száma $=12, \mathrm{~S}=0,0$ ).

\section{A VIZSGÁLATBAN ALKALMAZOTT TESZTEK ISMERTETÉSE}

A vizsgálatban hét, a frontális lebeny működésére érzékeny neuropszichológiai tesztet, illetve próbát alkalmaztunk. A teszteket nyugodt körülmények között, egy ülésben vettük fel. A vizsgálati ülés a betegekkel kb. 60-90 percet, a kontrollcsoport tagjaival 45-60 percet vett igénybe. Az alkalmazott tesztmódszerek a következők:

1. Rey-Osterrieth komplex ábra (REY, 1941 és OSTERRIETH, 1944, idézi LEZAK, 1995)

Ez a teszt a vizuopercepció, a vizuális organizáció és az incidentális téri memória vizsgálatára alkalmazott eljárás. A vizsgálati személy feladata először egy összetett geometriai ábra lemásolása, majd 20-30 másodperces késleltetési idő után annak emlékezetből történő reprodukciója. A rajzoláshoz meghatározott sorrendben különböző színű ceruzákat adunk a kezébe, így nyomon követhető a vizsgálati személy szervezési stratégiája. A teszt kiértékelése standardizált pontozási rendszer alapján történik. 
2. Rey 15 szó teszt (REY, 1964, idézi LEZAK, 1995)

Ez a teszt a rövid és hosszú távú verbális memória és az interferenciahatások vizsgálatára szolgál. Az első („A”) 15 szavas lista 5 tanulási próbáját egy második, szintén 15 szavas lista („B”) egyszeri felidézése követi. Ezután következik az első lista közvetlen felidézése, majd egy elterelő feladatot követően kb. 30 perc múlva annak késleltetett felidézése.

Az „A” lista első öt felidézési próbája alapján felrajzolható a vizsgálati személy tanulási görbéje. Az összteljesítményről az egyes próbák során felidézett szavak száma, a betolakodó szavak és a perszeverációk száma, valamint az interferenciahatások mutatói adnak információt.

\section{Hét fogás teszt (VERSEGHi, Pollák, HornyánSZKY, 1996)}

Ez a teszt vizuális ingeranyaggal dolgozó memóriapróba. 17 képet tartalmaz, melyek mind azonos kategórián belüli ingereket, nevezetesen ételek képeit ábrázolják. A vizsgálati személynek négy előzőleg kiemelt képet kell megjegyeznie és kiválasztania a megadott sorrendben bemutatott képek közül. Ez a próba négyszer zajlik le, ezalatt bizonyos képek több alkalommal is, mások egyszer sem kerülnek kiválasztásra a sorozat elején. Ezután kirakjuk az összes képet a vizsgálati személy elé egy meghatározott konfigurációban, majd arra kérjük, válassza ki azokat a képeket, melyek egyszer sem szerepeltek célingerként, illetve azokat a képeket kell felismernie, amelyek többször is kiemelésre kerültek az első négy próbában. Ezután összeszedjük a kártyákat, és arra kérjük a vizsgálati személyt, rakja ki a képeket úgy, ahogy azt az előbb látta. Ebben a tesztben a vizsgálati személynek komplex vizuális ingerekre kell emlékeznie, melyet nehezít, hogy mivel azonos kategóriába tartozó ingerekről van szó, a verbális mediáció lehetősége korlátozott.

\section{Piéron-teszt (Dulin, Csernyikné Póth, 1985)}

Ez teszt a klinikumban a mai napig széles körben alkalmazott figyelemvizsgáló eljárás. A tesztlapon 400 db négyzet látható, melyek sarkai, illetve oldalai különböző irányú kis vonalakkal vannak megjelölve. A lap tetején négy különbözően megjelölt négyzet van kiemelve, a vizsgálati személy feladata, hogy az ilyen négyzeteket megkeresse és áthúzza a 400 alakzat közül. Ehhez 5 perc áll rendelkezésére. Balról jobbra, soronként kell haladni, és minden sort csak egyszer lehet átnézni, így a négyféle ábrát egyszerre kell megjegyezni és figyelni. A teljesítmény egyik mutatója (n) az elemek száma, ameddig a vizsgálati személy eljutott. Egy másik mutató (T\%) a helyesen áthúzott elemek száma elosztva az n-ig terjedő összes áthúzandó elem számával. A hibázások jellege is fontos, ezek lehetnek téves riasztások és kihagyások. 
5. Térileg elrendezett szubjektív szerveződéses felidézéses feladat (TESSZ) (VERSEGHI, 1997)

Ez a teszt a vizuális-téri és a verbális memóriát is igénylő feladat. A vizsgálati személy elé kirakunk 12 féle tárgyat (pl. gemkapocs, kokárda), és 12 db piros müanyag dobozt az óra számlapjának megfelelő elrendezésben. A vizsgálati személy feladata az, hogy helyezze el e tárgyakat a dobozokban (mindegyikbe egy féle tárgyat) oly módon, hogy utána vissza tudjon emlékezni arra, hogy mit hova rakott. Az első felidézés után a vizsgálati személynek adunk egy kis segítséget a felidézéshez, és újra ellenőrizheti a dobozok tartalmát a második felidézési próba előtt. Végül arra kérjük a vizsgált személyt, sorolja fel a 12 tárgyat.

6. és 7. Motoros próbák: ritmuskopogás (LURIJA, 1975), ököl-tenyér-él próba (LEZAK, 1995)

Ezeket az egyszerű motoros próbákat a mozgásprogramozás vizsgálata céljából alkalmaztuk. A ritmuskopogási próbában a vizsgálati személynek először egyszerű, majd komplexebb ritmusstruktúrák lekopogását kell utánoznia, pl. két hosszú, majd három rövid ütést. Az ököl-tenyér-él próbában háromszor bemutatjuk a vizsgálati személynek a próba neve által jelzett egyszerű mozdulatsort. Neki ezt jobb, majd bal kézzel le kell utánoznia. Amennyiben nem sikerül a mozdulatsort leutánozni, újra bemutatjuk hangosan kopogva a mozdulatokkal, ha így sem megy, verbális mediációval próbálunk segíteni, és ha ez sem válik be, akkor kinesztéziás mediációt alkalmazunk.

\section{EREDMÉNYEK}

A tesztek eredményeit Vargha András MiniStat nevű programjának segítségével elemeztük. A mintákat a tesztek részeredményei, azaz összesen 44 változó mentén hasonlítottuk össze. Az első öt teszt változói esetében kétmintás t-próbát alkalmaztunk. A két minta szórásának szignifikáns eltérése esetén a Welch-féle d-próba eredményeit vettük figyelembe. A motoros próbák eredményeit a $\chi^{2}$-próba alkalmazásával dolgoztuk fel.

Az eredmények nagy része megerősítette hipotéziseinket. Az elvárásoknak megfelelően a Rey-Osterrieth-ábra alapján szignifikáns eltérés mutatkozik a szkizofrén személyek és a kontrollcsoport tagjai között. A két minta másolási $(\mathrm{p}<0,05)$ és felidézési $(\mathrm{p}<0,01)$ pontszámai jelentősen különböznek egymástól a kontrollcsoport javára. A felidézés és a másolás százalékos aránya tekintetében ugyanilyen irányú eltérés tapasztalható a két csoport között ( $\mathrm{p}<0,05)$, ami azt mutatja, hogy a kontrollcsoport tagjainál erősebb összefüggés van a másolás és a felidézés pontszámai között, mint a betegeknél. 
1. táblázat. A szkizofrén betegek és a kontrollcsoport összehasonlítása a Rey-Osterrieth komplex ábra pontszámai alapján

\begin{tabular}{|l|c|c|c|c|c|c|}
\hline \multirow{2}{*}{ Változó neve } & \multicolumn{2}{|c|}{ Szkizofrének } & \multicolumn{2}{c|}{ Egészségesek } & \multirow{2}{*}{$\begin{array}{c}\text { t-érték } \\
\text { d-érték }\end{array}$} & \multirow{2}{*}{ p-érték } \\
\cline { 2 - 5 } & Átlag & Szórás & Átlag & Szórás & d-én \\
\hline R-O Másolás & 31,56 & 4,035 & 35,40 & 0,459 & $\mathrm{~d}(8)=2,84$ & 0,05 \\
\hline R-O Felidézés & 15,61 & 5,857 & 23,95 & 4,317 & $\mathrm{t}(17)=3,56$ & 0,01 \\
\hline F/M\% & 50,29 & 19,59 & 67,70 & 12,47 & $\mathrm{t}(17)=2,34$ & 0,05 \\
\hline
\end{tabular}

A Piéron-tesztben is szignifikánsan jobban teljesítettek az egészséges személyek, mint a szkizofrén betegek, akik átlagosan csak a 164. alakzatig jutottak el $(\mathrm{p}<0,01)$. A T\% is magasabb volt a kontrollcsoportban $(\mathrm{p}<0,05)$, ami arra utal, hogy ők az átnézett négyzetek számához képest szignifikánsan kevesebb hibát vétettek, mint a szkizofrén betegek. A kihagyások és a téves riasztások számának tekintetében azonban nem különbözik egymástól a két minta.

2. táblázat. A szkizofrén és egészséges személyek összehasonlítása a Piéron-teszt mutatói alapján

\begin{tabular}{|l|c|c|c|c|c|c|}
\hline \multirow{2}{*}{$\begin{array}{c}\text { Változó } \\
\text { neve }\end{array}$} & \multicolumn{2}{|c|}{ Szkizofrének } & \multicolumn{2}{c|}{ Egészségesek } & \multirow{2}{*}{$\begin{array}{c}\text { t-érték } \\
\text { d-érték }\end{array}$} & \multirow{2}{*}{ p-érték } \\
\cline { 2 - 5 } & Átlag & Szórás & Átlag & \multicolumn{1}{c|}{ Szórás } & \\
\hline $\mathrm{n}$ & 164,10 & 43,20 & 323,00 & 75,08 & $\mathrm{~d}(14)=5,80$ & 0,01 \\
\hline $\mathrm{T}$ & 84,23 & 17,13 & 96,59 & 1,465 & $\mathrm{~d}(9)=2,27$ & 0,05 \\
\hline kihagyás & 14,20 & 17,57 & 6,20 & 3,293 & $\mathrm{~d}(10)=1,41$ & nem szign. \\
\hline
\end{tabular}

A Rey 15 szó teszt eredményei szerint az egészséges személyek több szót tudnak megtanulni a próbák során, mint a szkizofrén betegek. A két csoport közötti különbség az „A” lista első hat felidézése és a „B” lista felidézése tekintetében szignifikáns, az „A” lista hetedik, késleltetett felidézése tekintetében erősen szignifikáns. A két vizsgálati csoport tanulási görbéjét az „A” lista első öt felidézési próbája alapján az 1. és 2. ábra mutatja, melyeken látható, hogy mindkét csoportnál a harmadik próbánál van egy törés a görbén, és hogy utána a szkizofrének görbéje kicsit meredekebben emelkedik, mint a kontrollszemélyeké. A szkizofrén betegek tanulási görbéje tehát nem lapos, mint ahogy azt a frontális betegek esetében leírták, ugyanakkor különbözik valamelyest az egészséges személyekétől. A perszeverációk száma elvárásainkkal összhangban szignifikánsan magasabb a szkizofrén betegeknél, mint a kontrollcsoportban $(\mathrm{p}<0,05)$, azonban a proaktív és retroaktív interferencia mutatói tekintetében nincs jelentős különbség a két csoport között. 
3. táblázat. A szkizofrén betegek és a kontrollcsoport összehasonlítása a Rey 15 szó teszt pontszámai alapján

\begin{tabular}{|l|c|c|c|c|c|c|}
\hline \multirow{2}{*}{ Változó neve } & \multicolumn{2}{|c|}{ Szkizofrének } & \multicolumn{2}{c|}{ Egészségesek } & \multirow{2}{*}{$\begin{array}{c}\text { t-érték } \\
\text { d-érték }\end{array}$} & \multirow{2}{*}{ p-érték } \\
\cline { 2 - 5 } & Átlag & Szórás & Átlag & Szórás & (19) \\
\hline A1 & 4,30 & 2,359 & 7,60 & 2,07 & $\mathrm{t}(18)=3,33$ & 0,01 \\
\hline A2 & 6,00 & 2,16 & 9,90 & 1,853 & $\mathrm{t}(18)=4,33$ & 0,01 \\
\hline A3 & 7,80 & 2,898 & 12,00 & 1,414 & $\mathrm{~d}(13)=4,12$ & 0,01 \\
\hline A4 & 9,00 & 2,449 & 13,00 & 1,155 & $\mathrm{~d}(13)=4,67$ & 0,01 \\
\hline B1 & 11,00 & 2,539 & 14,00 & 1,333 & $\mathrm{~d}(14)=3,31$ & 0,01 \\
\hline A6 & 5,00 & 1,491 & 7,60 & 1,265 & $\mathrm{t}(18)=4,21$ & 0,01 \\
\hline A7 & 8,40 & 2,633 & 12,10 & 2,283 & $\mathrm{t}(18)=3,36$ & 0,01 \\
\hline Perszev. & 8,60 & 3,596 & 12,00 & 2,406 & $\mathrm{t}(18)=2,70$ & 0,05 \\
\hline Betolak. szavak & 5,30 & 5,314 & 1,30 & 2,163 & $\mathrm{~d}(12)=2,20$ & 0,05 \\
\hline Proaktív interf. & 2,30 & 4,296 & 0,30 & 0,483 & $\mathrm{~d}(9)=1,46$ & nem szign. \\
\hline Retroaktív interf. & 0,60 & 0,843 & 0,10 & 0,316 & $\mathrm{~d}(11)=1,76$ & nem szign. \\
\hline
\end{tabular}

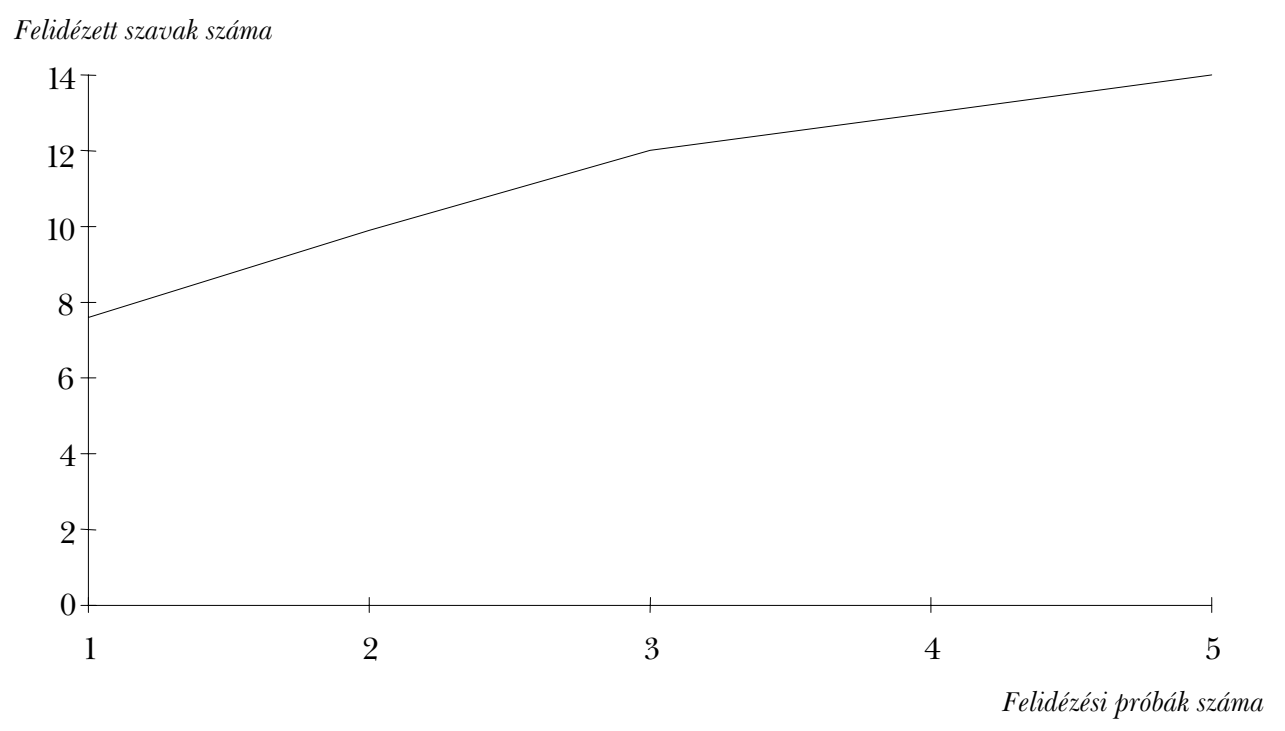

1. ábra. A kontrollcsoport tanulási görbéje 
Felidézett szavak száma

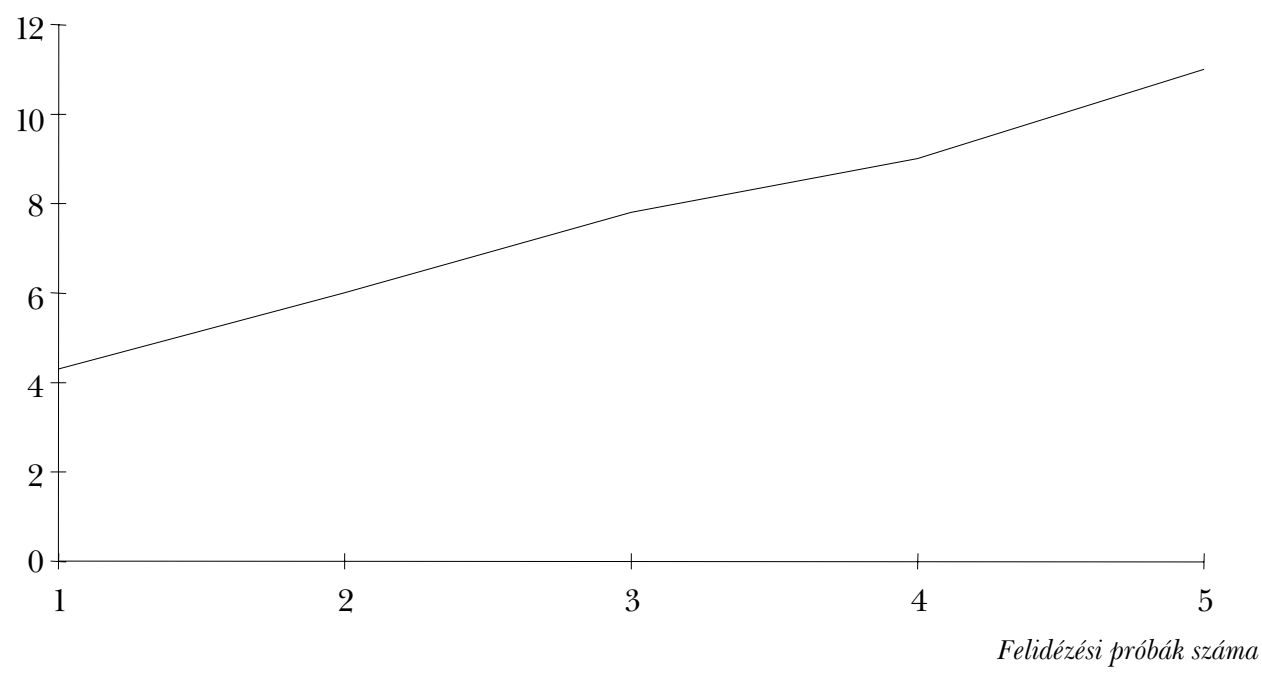

2. ábra. A szkizofrén betegek tanulási görbéje

A Hét fogás teszt első négy próbája eredményeinek összesített mutatója jelentősen különbözik a két mintában $(\mathrm{p}<0,01)$, jelezve ezzel, hogy a szkizofrén betegek kevesebb képet ismertek fel, mint a kontrollszemélyek, és szignifikánsan többet hibáztak $(\mathrm{p}<0,01)$. Az ötödik és a hatodik próbákban a betegeknél szignifikánsan több negatív választás tapasztalható a pozitív választások számához viszonyítva, mint a kontrollcsoport tagjainál, és náluk a kihagyások száma is magasabb. A hetedik, vizuális-téri memóriát tesztelő részfeladatban is lényegesen jobban teljesítettek az egészségesek, mint a szkizofrének $(\mathrm{p}<0,05)$.

A TESSZ feladat eredményei szintén alátámasztják hipotézisünket. Az első próba során a szkizofrén betegek kevesebb tárgy helyét tudták felidézni, mint az egészséges személyek $(\mathrm{p}<0,05)$, és a második felidézés eredménye szempontjából még markánsabb ez a különbség $(\mathrm{p}<0,01)$. Ezenfelül a betegek kevesebb tárgy nevét tudták felidézni a teszt végén, mint a kontrollcsoport tagjai $(\mathrm{p}<0,01)$.

A motoros próbák eredményei is az elvárásoknak megfelelően alakultak. A ritmuskopogási próbában az egészséges személyek mindegyike tökéletesen végrehajtotta a feladatot, míg a szkizofrén betegek mindössze fele volt képes erre $(\mathrm{p}<0,01)$. Az ököl-tenyér-él próbát jobb kézzel a kontrollcsoport minden tagja különösebb nehézség nélkül végrehajtotta, míg a szkizofrén betegek közül ezt csak hárman tudták megcsinálni. Négy betegnek elég volt a verbális mediáció, ám kettőnél kinesztéziás mediációval is nehezen ment a cselekvéssor végrehajtása. A két minta tehát szignifikánsan különbözik egymástól a jobb kezes ököl-tenyér-él 
próba végrehajtása tekintetében $(\mathrm{p}<0,01)$. A bal kézzel való végrehajtás az egészséges személyek közül nyolcnak tökéletesen sikerült első bemutatásra, két személynek verbális mediációra volt szüksége. A szkizofrének közül csak egy személy tudta elsőre megcsinálni a mozdulatsort, öten verbális mediációval, négyen pedig csak kinesztéziás mediációval tudták végrehajtani a feladatot. A két csoport közötti különbség e tekintetben erősen szignifikáns $(\mathrm{p}<0,01)$.

4. táblázat. A szkizofrén betegek és a kontrollcsoport összehasonlítása a Hét fogás teszt részpontszámai alapján

\begin{tabular}{|l|r|r|r|c|c|c|}
\hline \multirow{2}{*}{ Változó neve } & \multicolumn{2}{|c|}{ Szkizofrének } & \multicolumn{2}{c|}{ Egészségesek } & \multirow{2}{*}{$\begin{array}{c}\text { t-érték } \\
\text { d-érték }\end{array}$} & \multirow{2}{*}{ p-érték } \\
\cline { 2 - 5 } & Átlag & Szórás & Átlag & Szórás & & \\
\hline 1 & 3,70 & 0,483 & 3,90 & 0,316 & $\mathrm{t}(18)=1,10$ & nem szign. \\
\hline 2 & 3,20 & 0,919 & 3,70 & 0,675 & $\mathrm{t}(18)=1,39$ & nem szign. \\
\hline 3 & 3,10 & 0,994 & 3,50 & 0,527 & $\mathrm{~d}(14)=1,12$ & nem szign. \\
\hline 4 & 3,30 & 0,483 & 3,70 & 0,483 & $\mathrm{t}(18)=1,85$ & 0,1 \\
\hline $1-4$ & 13,30 & 1,160 & 14,80 & 1,135 & $\mathrm{t}(18)=2,92$ & 0,01 \\
\hline Téves riasztás & 3,70 & 2,312 & 0,90 & 1,449 & $\mathrm{t}(18)=3,25$ & 0,01 \\
\hline Persz. 1 & 0,60 & 0,516 & 0,10 & 0,316 & $\mathrm{~d}(15)=2,61$ & 0,05 \\
\hline Persz. 2 & 1,00 & 1,333 & 0,20 & 0,422 & $\mathrm{~d}(11)=1,81$ & 0,1 \\
\hline $5+$ & 2,10 & 1,524 & 2,60 & 0,516 & $\mathrm{~d}(11)=0,98$ & nem szign. \\
\hline 5 hiány\% & 47,84 & 26,92 & 23,80 & 24,50 & $\mathrm{t}(18)=2,09$ & 0,1 \\
\hline $6+$ & 1,10 & 0,876 & 1,80 & 0,632 & $\mathrm{t}(18)=2,05$ & 0,1 \\
\hline 6 6hiány\% & 62,32 & 33,86 & 17,66 & 24,03 & $\mathrm{t}(18)=3,40$ & 0,01 \\
\hline 7 & 7,95 & 3,954 & 11,40 & 2,644 & $\mathrm{t}(18)=2,29$ & 0,05 \\
\hline
\end{tabular}

5. táblázat. A szkizofrén betegek és a kontrollcsoport összehasonlítása a Térileg elrendezett szubjektív szerveződéses felidézéses feladat eredményei alapján

\begin{tabular}{|l|c|c|c|c|c|c|}
\hline \multirow{2}{*}{ Változó neve } & \multicolumn{2}{|c|}{ Szkizofrének } & \multicolumn{2}{c|}{ Egészségesek } & \multirow{2}{*}{$\begin{array}{c}\text { t-érték } \\
\text { d-érték }\end{array}$} & \multirow{2}{*}{ p-érték } \\
\cline { 2 - 5 } & Átlag & Szórás & Átlag & Szórás & \\
\hline 1. felidézés & 6,60 & 3,471 & 9,80 & 2,251 & $\mathrm{~d}(15)=2,45$ & 0,05 \\
\hline 2. felidézés & 8,60 & 2,989 & 12,00 & 0,00 & $\mathrm{~d}(9)=3,60$ & 0,01 \\
\hline Felsorolás & 10,70 & 1,252 & 12,00 & 0,00 & $\mathrm{~d}(9)=3,28$ & 0,01 \\
\hline
\end{tabular}


6. táblázat. A szkizofrén betegek és a kontrollcsoport összehasonlítása a ritmuskopogási próba alapján $\chi^{2}=6,667(p<0,01)$

\begin{tabular}{|c|c|c|}
\cline { 2 - 3 } \multicolumn{1}{c|}{} & Szkizofrének & Egészségesek \\
\hline Hibátlanul utánoz & 5 & 10 \\
\hline Szétesett a ritmus & 5 & 0 \\
\hline
\end{tabular}

7. táblázat. A szkizofrén betegek és a kontrollcsoport összehasonlítása az ököl-tenyér-él próba alapján $\chi^{2}=9,744(p<0,01)$

\begin{tabular}{|l|c|c|}
\cline { 2 - 3 } \multicolumn{1}{c|}{} & Szkizofrének & Egészségesek \\
\hline $\begin{array}{l}\text { Első vagy második bemutatásra } \\
\text { sikeres }\end{array}$ & 3 & 10 \\
\hline Verbális mediációval sikeres & 4 & 0 \\
\hline Kinesztéziás mediáció szükséges & 2 & 0 \\
\hline
\end{tabular}

\section{AZ EREDMÉNYEK KVALITATÍV ELEMZÉSE}

A statisztikai elemzés alapján látható, hogy a szkizofrén betegek teljesítménye szignifikánsan eltér az egészséges személyekétől. A szkizofrén csoport eredményei azonban nemcsak mennyiségileg, hanem minőségileg is mások, mint a kontrollcsoportéi. Hibáik jellege sok tekintetben hasonlít a frontális betegeknél tapasztalható típushibákra.

A Rey-Osterrieth tesztben a szkizofrén betegeknél szembetűnő a lemásolt, illetve az emlékezetből felidézett ábra viszonylagos szétesettsége az egészséges személyek által rajzolt ábrákhoz képest. Rajzaik kevésbé szervezettek és precízek, mint az egészséges személyekéi, gyakoriak bennük az aránytalanságok, és e különbség legmarkánsabban az emlékezetből történő rajzolás esetén jelentkezett. Ez a frontális lebeny érintettségére utaló jegy, mivel a homloklebeny felelős az információk aktív szervezéséért, ez pedig nagyban hozzájárul a felidézés sikerességéhez.

A Piéron-tesztben a figyelemzavar az átnézett négyzetek alacsony és a hibázások magas számában nyilvánult meg. A szkizofrén betegeknél a figyelmi deficit egyik jellegzetes formája a figyelem letapadása, ami perszeverációként is felfogható. A figyelemzavar másik formája a figyelem ugrálása, amely nagyszámú elem áttekintését eredményezi sok hibával. Ez a két stratégia mind a betegeknél, mind az egészséges személyeknél megtalálható volt, ám a betegeknél hangsúlyosabban jelentkezett, és jelentősen rontotta a teljesítményt.

A Rey 15 szó tesztben is tapasztalhatók perszeverációk a betegcsoportban. A szkizofrén személyek gyakran ismételtek meg egy-egy szót ugyanazon felidézési próba alatt, és ennek nem is voltak tudatában. A perszeverációk a viselkedés monitorozásának deficitjére utalnak: a személy nem képes megfelelő kontrollt gyakorolni cselekedetei felett, így hibakorrekcióra sem képes. 
A Hét fogás tesztben is több perszeveráció és kihagyás tapasztalható a szkizofrén betegeknél, mint a kontrollszemélyeknél. Ezek a hibák feltehetően összefüggnek a betegeknél viselkedéses szinten is tapasztalható figyelemzavarral.

A Térileg elrendezett szubjektív szerveződéses felidézéses feladat nagyon jól mutatja a szkizofrén betegek frontális diszfunkcióját. A betegek többség nem alkalmazott aktív szervezési stratégiát a tárgyak elhelyezése és felidézése során. Az aktív részvétel hiányát és a figyelem deficitjét tükrözi az is, hogy a betegek többsége nem tudta felidézni az összes tárgy nevét, míg ezt a kontrollcsoport minden tagja könnyedén megtette.

A motoros próbákban nyújtott teljesítmény alapján is valószínűsíthető a frontális lebeny érintettsége a szkizofrén mintában. A ritmuskopogás próbában a ritmus szétesettsége az idői rend károsodását mutatja. A betegek vissza tudták adni a kopogások számát, ám maga a ritmus elveszett. A cselekvési program érintettsége az ököl-tenyér-él próbánál még hangsúlyosabban megmutatkozott. A szkizofrén betegek többsége nehézségekkel küszködött e próbában, főleg a bal kézzel végzett mozdulatsor végrehajtásánál. Legszembetűnőbben akkor jelentkezett ez a probléma, amikor a betegnek át kellett térnie az ököl-tenyér-él mozgássorról az ökölél-tenyér kombinációra. Ekkor a betegek többsége az addig ismételt mozdulatsort folytatta, vagy perszeverálni kezdett. Perszeverációk gyakran jelentkeztek a próba alatt, és a mozdulatot sokszor verbális mediáció segítségével sem sikerült végrehajtani. Ez a jelenség a cselekvési program tehetetlenségének következménye, és az eddig leírt tünetek mellett ez is a frontális lebeny érintettségére utal.

\section{KÖVETKEZTETÉSEK}

A kapott eredmények arról tanúskodnak, hogy a szkizofrén betegek teljesítménye szignifikánsan rosszabb az egészséges személyekénél a vizsgálatban alkalmazott tesztekben, valamint hogy hibáik jellege a frontális lebeny sérülése esetén megfigyelhető specifikus hibákhoz hasonló.

Az információ aktív szervezésének hiányát tükrözik szkizofrén betegeinknél a Rey-Osterrieth komplex ábra és a Térileg elrendezett szubjektív szerveződéses felidézéses feladat eredményei. A verbális memóriatesztben az egészséges személyekhez képest nyújtott rosszabb teljesítmény a szavak kategorizálásának és a válaszok monitorozásának károsodását mutatja. A tartós figyelem deficitjére a Piéronteszt mutatói, a figyelemmegosztás zavarára pedig a Hét fogás teszt és a Piéronteszt eredményei utalnak. A mozgásprogramozás károsodása a motoros próbákban volt kimutatható. Az öngenerált cselekvések monitorozásának zavara a legtöbb teszt eredményeiben megmutatkozott perszeverációk formájában, valamint az önkorrekció csökkent képességében.

Az eredmények tehát a vizuopercepció és a vizuális organizáció, a verbális memória, az incidentális és a szelektív figyelem, a verbális és téri-vizuális memória és a mozgásprogramozás károsodására utalnak szkizofrén vizsgálati személyeinknél. E deficitek hátterét a figyelem- és az információfeldolgozás zavara, az aktív 
szervezés hiánya, a cselekvések programozásának és ez utóbbiból következően az öngenerált viselkedés regisztrálásának károsodása képezi.

E vizsgálat eredményei arra utalnak, hogy a neuropszichológiai vizsgálóeljárások jól alkalmazhatók pszichiátriai betegeknél a diagnosztikában, és talán hasznosak lehetnek a terápiás terv és a komplexebb rehabilitációs program kialakítása során is.

\section{IRODALOM}

BÁnki M. Cs. (1994) Szkizofrénia: neurotranszmisszió és farmakoterápia. In Bitter I., Füredi J. (szerk.) Szkizofrénia. 24-43. Cserépfalvi Könyvkiadó, Psychoeducatio-Léleknevelés Alapítvány, Budapest

Berman, K. F., Illowsky, P. B., Weinberger, D. R. (1988) Physiological dysfunction of dorsolateral prefrontal cortex in schizophrenia. Archives of General Psychaiary, 45, 616622.

Berman, K. F., Weinberger, D. R., Shelton, R. C., Zec, R. F. (1987) A relationship between anatomical and physiological brain pathology in schizophrenia: Lateral cerebral ventricular size predicts cortical blood flow. American Journal of Psychiatry, 144, 12771282.

Buchsbaum, M. S., Nuechterlein, K. H., Haier, R. J., Wu, J., Sicotte, N., Hazlett, E., Asarnow, R., Potkin, S., Guich, S. (1990) Glucose metabolic rate in normals and schizophrenics during the continuous performance test assessed by positron emission tomography. British Journal of Psychiatry, 156, 216-227.

Cannon, T. D., van Erp, T. G. M., Huttunen, M. et al. (1998) Regional gray matter, white matter, and cerebrospinal fluid distributions in schizophrenic patients, their siblings, and controls. Arcives of General Psychiatry, 55, 1084-1091.

Chen, E. Y. H., Wilkins, A. J., McKenna, P. J. (1994) Semantic memory is both impaired and anomalous in schizophrenia. Psychological Medicine, 24, 193-202.

Cullum, C. M., Harris, J. G., Waldo, M. C., Smernoff, E. et al. (1993) Neurophysiological and neuropsychological evidence for attentional dysfunction in schizophrenia. Schizophrenia Research, 10, 131-141.

DABASI G. (1994) Agyi PET és SPECT vizsgálatok jelentősége szkizofréniában. In Bitter I., Füredi J. (szerk.) Szkizofrénia. 116-127. Cserépfalvi Könyvkiadó, Psychoeducatio-Léleknevelés Alapítvány, Budapest

Dawson, M. E., Hazlett, E. A., Filion, D. L., Nuechterlein, K. H. et al. (1993) Attention and schizphrenia: Impaired modulation of the startle reflex. Journal of Abnormal Psychology, 102, 633-641.

Degrell, I. (1998) Agyi képalkotó eljárások. In Füredi J. (szerk.) A pszichiátria magyar kézikönyve. 181-204. Medicina Könyvkiadó, Budapest

Dulin, J., Csernyikné Póth Á. (1985) A Piéron figyelemvizsgáló teszt tesztkönyve. Munkalélektani koordinációs tanács Módszertani sorozata, 5. kötet, Munkaügyi Kutatóintézet, Budapest

Frame, C. L., Oltmans, T. F. (1982) Serial recall by schizophrenic and affective patients during and after psychotic episodes. Journal of Abnormal Psychology, 91, 311-318. 
Franzen, G., Ingvar, D. H. (1975) Absence of activation in frontal structures during psychological testing of chronic schizophrenics. Journal of Neurology, Neurosurgery and Psychiatry, 38, 1027-1032.

Gold, J. M., Randolph, C., Carpenter, C. J., GoldberG, T. E. et al. (1992) Forms of memory failure in schizophrenia. Journal of Abnormal Psychology, 101, 487-494.

Gray, J. A., Feldon, J., Rawlins, J. N. P., Hemsley, D. R., Smith, A. D. (1991) The neuropsychology of schizophrenia. Behavioral and Brain Sciences, 14, 1-84.

Jeste, D. V., Galasko, D., Corey-Bloom, J., Walens, S., Granholm, E. (1996) Neuropsychiatric aspects of the schizophrenias. In Fogel, B. S., Schiffer, R. B., Rao, S. M. (eds) Neuropsychiatry. 325-344. Williams \& Wilkins, Baltimore, Maryland

KENÉz J. (1994) A digitális képalkotás szerepe és jelentősége a szkizofréniában. In Bitter I., Füredi, J. (szerk.) Szkizofrénia. 96-115. Cserépfalvi Könyvkiadó, Psychoeducatio-Léleknevelés Alapítvány, Budapest

Kinsbourne, M., Hicks, R. E. (1978) Functional cerebral space: A model for overflow, transfer and interference effects in human performance. In Requin, J. (ed.) Attention and performance, VII., 345-362. Erlbaum, Hillsdale

Levin, S., Yurgelun-Todd, D., Craft, S. (1989) Contributions of clinical neuropsychology to the study of schizophrenia. Journal of Abnormal Psychology, 9, 341-356.

LEZAK, M. D. (1995) Neuropsychological assessment. Oxford University Press, New York-Oxford

LurijA, A. R. (1975) A mozgásperszeverációk két típusáról. In Lurija, A. R. Válogatott tanulmányok. 146-158. Gondolat Könyvkiadó, Budapest

Maher, B. A., Manschreck, T. C., Rucklos, M. E. (1980) Contextual constrint and the recall of verbal material in schizophrenia: The effect of thought disorder. British Journal of Psychiatry, 137, 69-73.

Osterrieth, P. A. (1944) Le test de copie d'une figure complexe. Archives de Psychologie, 30, 206-356.

Paulman, R. G., Devous, M. D., Gregory, R. R., Herman, J. H. et al. (1990) Hypofrontality and cognitive impairment in schizophrenia: Dynamic single-photon tomography and neuropsychological assessment of schizophrenic brain function. Biological Psychiatry, 27, 377-399.

Posner, M. I., Early, T. S., Reiman, E., Pardo, P. J., Dhawan, M. (1988) Asymmetries in hemispheric control of attention in schizophrenia. Archives of General Psychiatry, 45, 814821.

REY, A. (1941) L'examen psychologique dans les cas d'encéphalopathie traumatique. Archives de Psychologie, 28, 286-340.

Rey, A. (1964) L'emamen clinique en psychologie, Presses Universitaires de France, Paris

Saykin, A. J., Shtasel, D. I., Gur, R. E. et al. (1994) Neuropsychological deficits in neuroleptic naive patients with first-episode schizophrenia. Archives of general Psychiatry, 51, 124-131.

Schwartz, B. L., Rosse, R. B., Deutsch, S. I. (1992) Toward a neuropsychology of memory in schizphrenia. Special Feature: Neuropsychological factors in mental disorders and their treatments. Psychopharmacology Bulletin, 28, 341-351. 
Seidman, L. J., Yurgelun-Todd, D., Kremen, W. S., Woods, B. T., Goldstein, J. M., FARAONE, S. V. (1994) Relationships of prefrontal and temporal lobe MRI measures to neuropsychological performance in chronic schizophrenia. Biological Psychiatry, 35, 235246.

Sengel, R. A., Lovallo, W. R. (1983) Effects of cueing on immediate and recent memory in schizophrenics. The Journal of Nervous and Mental Disease, 171, 426-430.

Stevens, A. A., Goldman-Rakic, P. S., Gore, J. C. et al. (1998) Cortical dysfunction in schizophrenia during auditory word and tone working memory demonstrated by functional magnetic resonance imaging. Archives of General Psychiatry, 55, 1097-1103.

Taylor, M. A., Abrams, R. A. (1984) Cognitive impairment in schizophrenia. American Journal of Psychiatry, 141, 196-201.

Verseghi A. (1997) Neuropszichológiai diagnosztika és rehabilitáció. Előadás, Egészségpszichológia program, 1997. november 3. ELTE, Budapest

Verseghi A., Pollák I., Hornyánszky M. (1996) A „Hét fogás” memóriavizsgálat. A Magyar Pszichológiai Társaság XII. Országos Tudományos Konferenciája, Budapest

Weinberger, D. R., Berman, K. F., Illowsky, B. P. (1988) Psychological dysfunction of dorsolateral prefrontal cortex in schizophrenia. Archives of General Psychiatry, 45, 609615 .

Wexler, B. E., Stevens, A. A., Bowers, A. A. et al. (1998) Word and tone working memory deficits in schizophrenia. Archives of General Psychiatry, 55, 1093-1096.

\title{
A NEUROPSYCHOLOGICAL STUDY OF HYPOFRONTALITY IN SCHIZOPHRENIC PATIENTS
}

\begin{abstract}
SZABÓ, JUDIT
The clinical observations according to which the negative symptoms of schizophrenia are similar to those that appear in the case of lesions of the frontal lobe, especially the prefrontal region drew attention to the role of the frontal lobe in the patomechanism of schizophrenia. The findings of the studies using structural and functional neuroimaging techniques and neuropsychological tests gave support to this idea.

The study presented in this paper aims at investigating the symptoms of hypofrontality in schizophrenia using neuropsychological methods. Tests of attention, verbal and visual memory, visuoperception, visuoconstruction, and simple motor tasks were administered to schizophrenic patients and healthy control subjects. According to our hypothesis the performance of the schizophrenic group would be poorer than that of the control group concerning both quantitative measures and qualitative variables, that is the types of errors. The results support the hypothesis; the poor performance of the schizophrenic patients were mostly due to perseveration errors, lack of organization and planning, and severe attentional deficit. The purpose of this paper is to point out that neuropsychological tests can be useful in the case of psychiatric patients in diagnostic work, in therapy and during the rehabilitation process.
\end{abstract}

Key words: $\quad$ hypofrontality, cognitive deficit, attentional deficit, perseveration, deficit of planning 
